\title{
EFEKTIVITAS PROSES PEMBUATAN LAPORAN PERTANGGUNG JAWABAN BENDAHARA PENGELUARAN DENGAN SILABI
}

\author{
Kemas Welly Angga Permana \\ Program Studi Ekonomi Akuntansi, Universitas Sjakhyakirti, Palembang \\ E-mail : kemaswelly@unisti.ac.id
}

\begin{abstract}
ABSTRACK
This study aims to determine the process of making a treasurer accountability report at the BPKP Representative Office of South Sumatra Province. The research design used is associative quantitative. With indicators in accordance with Law Number 17 of 2003 concerning State Finances Article 35 paragraph (2); Regulation of the Minister of Finance Number 190 / PMK.05 / 2012 concerning the Position and Responsibility of the Treasurer; and Regulation of the Director General of Treasury Number 03 / PB / 2014 article 3 paragraph 7 states that all revenues and expenditures as referred to in Article 30 paragraph 1 shall be made with the SILABI application. The results showed that, the LPJ treasurer-making process was in accordance with the guidelines for the money it managed. At the BPKP Representative Office for the Province of South Sumatra, they only appoint an Expenditure Treasurer, to manage finances based on the Budget Activity Plan (RKA). Experience, certification, workload and welfare attached to the Expenditure Treasurer are in accordance with regulations. Application of the Agency Treasury Report System (SILABI) updated version 19.0.5. dated 20 May 2019, available and easy to download, use friendly, and there are instructions for use. Thus, the making of the Accountability Report (LPJ) of the spending treasurer is in accordance with statutory regulations, efficient, economical, effective and transparent to report.
\end{abstract}

Keywords : Accountability Report (LPJ), Expenditure Treasurer, SILABI Application

\section{ABSTRAK}

Era desentralisasi dan otonomi daerah menjadi tantangan bagi setiap daerah untuk memanfaatkan peluang dalam menggali potensi daerah. Upaya peningkatan pendapatan asli daerah (PAD) dapat dilakukan dengan meningkatkan efektivitas penerimaan retribusi dari sumber PAD khususnya retribusi daerah. Penelitian ini bertujuan untuk mengetahui dan menganalisis kontribusi retribusi izin pelayanan pemakaman terhadap penerimaan pendapatan asli daerah Kota Palembang tahun 2015-2019. Pemungutan retribusi telah diatur dalam Peraturan Daerah Nomor 12 Tahun 2015 tentang retribusi pelayanan pemakaman dan pengabuan mayat yang merupakan acuan dasar untuk memaksimalkan pelayanan administratif yang dikelola oleh Kecamatan Ilir Barat Satu Kota Palembang. Penelitian ini menggunakan metode analisis deskriptif kuantitatif. Teknik pengumpulan data dilakukan dengan menggunakan data sekunder melalui teknik dokumentasi. Data yang digunakan adalah retribusi izin pelayanan pemakaman. Metode Analisis yang di gunakan yaitu analisis kontribusi, yaitu suatu alat analisis yang digunakan untuk mengetahui seberapa besar kontribusi retribusi terhadap pendapatan asli daerah. Hasil penelitian adalah nilai kontribusi penerimaan retribusi izin pelayanan pemakaman menunjukkan adanya kecenderungan berfluktuasi tiap tahunnya presentase rata- rata kontribusi penerimaan retribusi izin pelayanan pemakaman dengan kriteria cukup baik mencapai 20,17\% artinya memberikan kontribusi terhadap Pendapatan Asli Daerah kota Palembang.

Kata kunci : Laporan Pertanggungjawaban (LPJ), Bendahara Pengeluaran, Aplikasi SILABI 


\section{PENDAHULUAN}

Bendahara Pengeluaran selaku pejabat fungsional yang bertanggung jawab kepada Kuasa Bendahara Umum Negara, wajib membukukan dan mempertanggung jawabkan seluruh uang negara yang dikuasainya. Disamping itu, selaku pejabat yang diangkat oleh Menteri/pimpinan lembaga, Bendahara Pengeluaran juga wajib membukukan seluruh transaksi dalam rangka pelaksanaan anggaran satuan kerja.

Badan Pengawasan Keuangan dan Pembangunan (BPKP) dengan tugas utama membantu Presiden mengawasi pengelolaan dan pertanggungjawaban keuangan negara serta pembangunan agar sesuai dengan ketentuan perundang-undangan yang berlaku, sekaligus memberikan masukan bagi penyusunan kebijakan yang terkait. Pada Kantor Perwakilan BPKP Provinsi Sumatera Selatan penyusunan dan penyajian laporan pertanggung jawaban bendahara pengeluaran mengacu pada Standar Akuntansi Pemerintahan (SAP) yang telah ditetapkan dengan Peraturan Pemerintah dengan benar dan tepat (Perwakilan BPKP Provinsi Sumatera Selatan, 2017)

Setelah melakukan pembuatan laporan pertanggungjawaban melalui aplikasi SILABI, bendahara pengeluaran akan melaporkan hasil kepada KPPN. Sesudah KPPN melakukan rekonsiliasi terhadap laporan tersebut, maka apabila sesuai laporan akan diterima dan apabila ditemukan selisih yang tidak disertai keterangan akan dikembalikan kembali. Dengan hal tersebut, menunjukan bahwa proses pembuatan laporan pertanggungjawaban masih ditemukan kendaladan hambatan.

Adanya kendaladan hambatan tersebut, sangat membahayakan akurasi dan validitas laporan pertanggung jawaban bendahara pengeluaran.Laporan pertanggung jawaban bendahara pengeluaran melalui aplikasi SILABI dimaksud kan untuk membantu bendahara pengeluaran dalam proses pembuatan laporan pertanggung jawaban, sehingga kerugian negara karena kelalaian oleh bendahara pengeluaran dapat diminimalisir, jadi pembuatan laporan pertanggung jawaban dengan menggunakan aplikasi SILABI merupakan wujud upaya bendahara pengeluaran untuk mengelola keuangan Negara secara tertib, efisien, efektif, transparan dan dapat dipertanggungjawab kan sesuai amanat undang-undang.

\section{TINJAUAN PUSTAKA}

\subsection{Laporan PertanggungJawaban}

Laporan pertanggungjawaban bendahara pengeluaran merupakan amanat dari UU Nomor 17 Tahun 2003 tentang Keuangan Negara pasal 35 ayat (2) yang menyatakan bahwa setiap orang yang diberi tugas menerima, menyimpan, membayar, dan/atau menyerahkan uang atau surat berharga atau barang-barang negara adalah bendahara yang wajib menyampaikan laporan pertanggung jawaban kepada Badan Pemeriksa Keuangan. Ketentuan lebih lanjut tentang pembuatan LPJ diatur dalam:

PP Nomor 8 tahun 2006, pasal 31 ayat (1); "Bendahara pengeluaran wajib menatausahakan dan menyusun laporan pertanggung jawaban atas uang yang dikelolanya dalam rangka pelaksanaan APBN".

1. PMK Nomor 162 tahun 2013, pasal 38 ayat (1); "Bendahara pengeluaran wajib menyusun LPJ setiap bulan atas uang/surat berharga yang dikelolanya".

2. Perdirjan Nomor 03 tahun 2014, pasal 10 ayat (1); "Bendahara pengeluaran wajib menyusun LPJ Bendahara secara bulanan atas uang yang dikelolanya".

Laporan pertanggungjawaban bendahara pengeluaran merupakan amanat dari UU Nomor 17 Tahun 2003 tentang Keuangan Negara pasal 35 ayat (2) yang menyatakan bahwa setiap orang yang diberi tugas menerima, menyimpan, membayar, dan/atau menyerahkan uang atau surat berharga atau barang-barang negara adalah 
bendahara yang wajib menyampaikan laporan pertanggungjawaban kepada Badan Pemeriksa Keuangan. Ketentuan lebih lanjut tentang pembuatan LPJ diatur dalam:

1. PP Nomor 8 tahun 2006, pasal 31 ayat (1); "Bendahara pengeluaran wajib menatausahakan dan menyusun laporan pertanggungjawaban atas uang yang dikelolanya dalam rangka pelaksanaan APBN".

2. PMK Nomor 162 tahun 2013, pasal 38 ayat (1); "Bendahara pengeluaran wajib menyusun LPJ setiap bulan atas uang/surat berharga yang dikelolanya".

3. Perdirjan Nomor 03 tahun 2014, pasal 10 ayat (1); "Bendahara pengeluaran wajib menyusun LPJ Bendahara secara bulanan atas uang yang dikelolanya".

Berdasarkan tugas bendahara pengeluaran, pencatatan dilakukan atas aktivitas penerimaan dan pengeluaran kas oleh bendahara pengeluaran. Aktivitas penerimaan kas mencakup semua penerimaan kas oleh bendahara pengeluaran. Contohnya adalah penerimaan uang dari penerbitan SP2D UP/TUP/GUP/LS Bendahara oleh KPPN, penerimaan uang dari pungutan pajak atas pembayaran yang dilakukan oleh bendahara pengeluaran, dan penerimaan lain yang menjadi hak negara, misalnya penerimaan denda atas keterlambatan penyerahan hasil pekerjaan oleh pihak ketiga atau penerimaan kembali belanja karena kelebihan pembayaran.

Aktivitas pengeluaran kas mencakup semua pengeluaran kas dari bendahara pengeluaran, baik untuk pembayaran belanja yang sudah definitif, pembayaran yang bersifat uang muka, maupun pengeluaran kas dalam rangka penyetoran pajak yang dipungut bendahara pengeluaran ke kas negara. Belanja yang sudah definitif adalah belanja yang sudah diserahterimakan barang/jasanya, misalnya pembayaran tagihan pengadaan ATK yang sudah diserahterimakan, pembayaran perjalanan dinas yang sudah dilaksanakan, dan pembayaran uang makan pegawai. Sedangkan pembayaran yang bersifat uang muka adalah pembayaran yang dilakukan di muka atas barang/jasa yang belum diterima, mendahului serah terima barang / pelaksanaan pekerjaan, misalnya pembayaran uang muka perjalanan dinas atau uang muka kerja.

Di samping itu, bendahara pengeluaran juga membukukan pembayaran langsung dari KPPN kepada pihak ketiga melalui SP2D LS. Dalam hal SP2D LS pihak ketiga, bendahara pengeluaran hanya membukukannya dalam buku pengawasan anggaran belanja saja.

\subsection{Bendahara Pengeluaran}

Menurut Undang-undang Nomor 17 Tahun 2003 pasal 35 ayat (2) disebutkan bahwa setiap orang yang diberitugas menerima, menyimpan, membayar, dan/atau menyerahkan uang atau surat berharga atau barang-barang negara adalah bendahara, yang wajib menyampaikan laporan pertanggungjawaban kepada Badan Pemeriksa Keuangan (BPK).

Undang-undang Nomor 1 Tahun 2004 pasal 1 nomor urut 14 menyebutkan bahwa bendahara adalah setiap orang atau badan yang diberi tugas untuk dan atas nama negara/daerah menerima, menyimpan, membayar, dan atau mengeluarkan uang/surat berharga/barang-barang milik negara/daerah.

Peraturan Menteri Keuangan Nomor 73/PMK.05/2008 tanggal 9 Mei 2008 pasal 3 ayat(4) menyebutkan bahwa Bendahara Pengeluaran adalah pejabat fungsional yang secara fungsional bertanggung jawab kepada Kuasa Bendahara Umum Negara atas pengelolaan uang yang menjadi tanggung jawabnya. Dari pengertian bendahara tersebut diatas, maka secara umum dapat dikatakan bahwa bendahara mempunyai tugas dan fungsi:

1. Menerima uang atau surat berharga / barang; 
2. Menyimpan uang atau surat berharga / barang;

3. Membayar / menyerahkan uang atau surat berharga/barang;

4. Menata usahakan uang atau surat berharga / barang;

5. Mempertanggung jawabkan uang atau surat berharga / barang yang berada dalam pengelolaannya.

\subsection{Sistem Laporan Bendahara Instansi (SILABI)}

Aplikasi SILABI adalah alat (tool) yang digunakan oleh bendahara untuk mempermudah pelaksanaan salah satu tugasnya. Di samping itu diintegrasikan ke dalam Aplikasi SPP-SPM dengan menambahkan tabel transaksi dan referensi yang dikhususkan untuk aplikasi SILABI. Aplikasi tersebut dirancang dapat mengurangi input data seminimal mungkin, dengan memanfaatkan data SPM sebagai salah satu sumber data input.

Sesuai dengan Peraturan Menteri Keuangan Nomor 162/PMK.05/2013 tentang Kedudukan dan Tanggung Jawab Bendahara pada Satuan Kerja Pengelola APBN Pasal 30 ayat 1 dan Peraturan Direktorat Jenderal Perbendaharaan Nomor 3/PB/2014 Pasal 3 ayat 1 , salah satu kewajiban saya sebagai bendahara adalah "menyelenggarakan pembukuan terhadap seluruh penerimaan dan pengeluaran yang dilakukan pada satker".

$$
\text { Pasal } 31 \text { ayat } 1 \text { PMK }
$$

162/PMK.05/2013 dan Perdirjen

Perbendaharan PER-3/PB/2014 Pasal 3 ayat

7 lebih lanjut menyatakan, "Pembukuan terhadap seluruh penerimaan dan pengeluaran sebagaimana dimaksud dalam Pasal 30 ayat (1) dilakukan dengan aplikasi yang dibuat dan dibangun oleh Kementerian Keuangan cq. Direktorat Jenderal Perbendaharaan".

Walaupun PMK 162 tersebut sudah disahkan sejak November tahun lalu dan walaupun gagasan mengenai aplikasi resmi dari Kementerian Keuangan yang bisa mengakomodasi tugas-tugas bendahara sudah muncul bertahun-tahun yang lalu, Kemenkeu melalui Dirjen Perben baru bisa meluncurkan aplikasi sesuai dengan yang dimaksud Pasal 31 ayat 1 awal caturwulan kedua tahun 2014 ini. Aplikasi ini diberi nama SILABI (Sistem Laporan Bendahara Instansi).

\subsection{Proses Pembuatan Laporan Pertanggungjawaban}

Proses pembuatan laporan bendahara pengeluaran merupakan pengurusan administrasi keuangan yang dilakukan di suatu instansi. Secara sederhana dapat didefinisikan sebagai kegiatan pencatatan transaksi keuangan. Transaksi keuangan yang dicatat oleh bendahara pengeluaran meliputi penerimaan kas, pengeluaran kas, perubahan posisi kas, dan perubahan kredit anggarandalam rangka pelaksanaan anggaran belanja dalam satuan kerja

Dasar Hukum : Peraturan Direktur Jenderal Perbendaharaan No. PER03/PB/2014tentang Petunjuk Teknis Penatausahaan, Pembukuaan, dan Pertanggungjawaban Bendahara pada Satuan Kerja Pengelola Anggaran Pendapatan dan Belanja Negara serta Verifikasi Laporan Pertanggungjawaban Bendahara.

Proses pembuatan laporan pertanggungjawaban bendahara pengeluaran disusun setiap bulan berdasarkan pembukuan bendahara yang telah direkonsiliasi dengan UAKPA.Sedangkan pencetakan Laporan Pertanggungjawaban Bendahara Pengeluaran dilaksanakan melalui aplikasi SAS Modul Bendahara Pengeluaran. Pencetakan LPJ bisa dilakukan apabila Bendahara telah merekam Berita Acara Pemeriksaan Kas dan Berita Acara Pemeriksaan Kas Modul ini juga sering disebut SILABI (Direktorat Sistem PerbendaharaanDirektorat Jenderal Perbendaharaan Kementerian Keuangan RI, 2018).

Direktorat Jenderal Perbendaharaan 
Kementerian Keuangan, aplikasi SAS harus mengupdate sampai dengan versi terbaru. Tersedianya Update aplikasi SAS versi terupdate, merupakan salah satu cara dalam rangka mengatasi permasalahan terkait level aplikasi SILABI didalam penyusunan LPJ Bendahara Pengeluaran (Buku Pintar Aplikasi SAS, 2018).

\subsection{PenelitianTerdahulu}

Berikut ini adalah beberapa penelitian terdahulu yang berkaitan dengan penelitian yang akan Peneliti lakukan, yaitu tentang penerapan Pasal 31 ayat 1 PMK 162/PMK.05/2013 dan Perdirjen Perbendaharan PER-3/PB/2014 Pasal 3 ayat 7 yang menjelaskan tentang penyusunan pelaporan keuangan berbasis aplikasi. Dari hasil penelitian-penelitian tersebut dijadikan landasan dan perbedaan dengan penelitian yang akan dilakukan oleh Peneliti:

1. Sari Junita (2017) membahas faktorfaktor yang mempengaruhi ketepatan waktu penyampaian laporan pertanggungjawaban Bendahara Pengeluaran SKPD dengan komitmen membahas kompetensi SDM, pendidikan dan pelatihan, disiplin kerja, motivasi, imlementasi, berpengaruh secara simultan dan parsial terhadap ketepatan waktu penyampaian.

2. Grace G Lewadu (2016) dlm "penelitiannya yg brjudul "Evaluasi Penatausahaan, penyusunan dan penyampaian laporan pertanggung jawaban hasil pembahasan peraturan pemerintah menjadi acuan dasar dalam melakukan fungsi penataanusahaan bendahara sehingga keuangan daerah dikelola secara tertib, taat pada aturan perundang-undang, efektif, efisien, ekonomis, transparan dan bertanggung jawab dengan memperhatikan asas keadilan, kepatuhan dan manfaat untuk masyarakat.

3. Nurmala (2016) dalam penelitiannya yang berjudul "Faktor faktor yang mempengaruhi ketepatan penyampaian pertanggungjawaban bendahara SKPK pada Pemerintah Kabupaten Aceh" bertujuan untuk mengetahui secara parsial interitas pelatihan penatausahaan dan prtanggung jawaban bendhara SKPK da Ambigugas peran positif terhadap ketepatan waktu penyampaian laporan.

\section{METODOLOGI PENELITIAN}

\subsection{Desain Penelitian}

Dalam penelitian ini, desain penelitian yang digunakan adalah kuantitatif asosiatif. Penelitian kuantitatif asosiatif adalah penelitian yang bertujuan untuk mengetahui hubungan dua variabel atau lebih (Sugiyono, 2013: 339). Desain penelitian ini merupakan rencana yang terstruktur dari penyelidikan yang digambarkan untuk memperoleh jawaban tentang penerapan aplikasi SILABI didalam proses pembuatan laporan pertanggungjawaban bendahara pengeluaran pada kantorPerwakilan BPKP Provinsi Sumatera Selatan.

\subsection{Jenis Penelitian}

Penelitian komparatif adalah peenelitian yang bersifat mmbndingkan. Pnelitian ini dilakukan untuk mmbandingkan persamaan dan peerbedaan dua atau lebih facta-facta dan sifat-sifat objek yang di teliti brdasarkan krangkaa pemmikiran tertentu. Pada penelitian ini variabelnya msih mandiri tetapi untuk sampel yang lebih dari satu atau dalam waktu yang berbeda.

\subsection{Teknik Pengumpulan Data}

Metode pengumpulan data dilakukan dengan mengumpulkan Metode ini dilakukan penulis yaitu pengumpulan data yang secara relevan dan teoritis melalui literatur-literatur, baik berupa undang-undang, peraturan pemerintah, surat edaran, makalah dan bukubuku yang berhubungan dengan perbendaharaan pengeluaran danrefrensi mengenaiaplikasi SILABI. 


\section{HASIL DAN PEMBAHASAN}

\subsection{Hasil Penelitian}

Berdasarkan hasil penelitian yang dilakukan, penulis berpendapat bahwa penggunaan aplikasi SILABI merupakan sebuah sistem informasi akuntansi yang dibuat khusus untuk Bendahara Pengeluaran, guna mempermudah kegiatan dan segala sesuatu yang berkaitan denganakuntansi transaksi keuangan.Aplikasi SILABI juga digunakan untuk mengolah data keuangan yang berhubungan dengan data transaksi dalam siklus akuntansi yang rutin. Hal tersebut terlihat dari adanya BKU, BP Kas Tunai, BP Bank, BP UP, BP LS Bendahara dan BP Pajak. Disamping hal tersebut terdapat menuperekaman/ pembuatan dokumen, pencatatan transaksi bendahara pengeluaran, dan pencetakan laporan pembukuan. Pada aplikasi SILABI juga memiliki kerahasiaan dan perlindungan data yang aman.

Berdasarkan

PMK

Nomor476/KMK.01/1991, bahwa Sistem Akuntansi Pemerintahan adalah suatu proses pengumpulan, penganalisaan, pengklasifikasian, pencatatan, peringkasan dan pelaporan terhadap suatu transaksi keuangan dari kesatuan ekonomi untuk menyediakan sebuah informasi keuangan.Peraturan Menteri Keuangan Nomor 162/PMK.05/2013 tentang penggunaan aplikasi SILABI, didalam proses pembuatan laporan pertanggungjawaban bendahara pengeluaran agar lebih efektif dan efisien.

Untuk menjalankan aplikasi SILABI diperlukan beberapa elemen agar sistem dapat berjalan dengan baik dan benar, sehingga dapat dijadikan informasi akuntansi yang relevan, diantaranya:

1. Bendahara Pengeluaran, yang sudah pengalaman dan sertifikasisehingga memahami proses akuntansi transaksi keuangan.
2. Aplikasi SILABI, yang versi terupdate untuk mencatat seluruh aktivitas akuntansi transaksi keuangan.

Kemudian menyajikannya dalam bentuk Laporan Pertanggungjawaban (LPJ) Bendahara Pengeluaran.Sehingga dengan menggunaan aplikasi SILABI bias menyediakan informasi akuntansi dan keuangan secara lengkap, akurat, relevan dan tepat waktu.

\subsection{Pembahasan}

Penyajian

Laporan

Pertanggungjawaban (LPJ) Bendahara Pengeluaran dengan aplikasi SILABI versi 19.0.5 untuk menciptakan karakteristik kualitas informasi akuntansi. Adapun karakteristik kualitas informasi akuntansi,yaitu:

1. Relevan, merupakan informasi yang perlu diketahui untuk memberikan pemahaman yang baru.

2. Tepat Waktu, merupakan faktor yang kritikal dalam menentukan kegunaannya.

3. Akurat, merupakan informasi yang harus bebas dari kesalahan.

4. Lengkap, artinya tidak ada bagian informasi yang esensial bagi pengambilan keputusan atau pelaksanaan tugas yang hilang. Informasi yang tidak lengkap bisa menimbulkan kesulitan, karena informasi yang tidak disertakan itu akan menjadi unsur ketidakpastian yang besar.

Berdasarkan PP No. 71 tahun 2010 pasal 1 ayat (3) tentang standar akuntansi pemerintahan, Standar akuntansi pemerintahan yang selanjutnya disingkat SAP, adalah prinsip-prinsip akuntansi yang diterapkan dalam menyusun dan menyajikan laporan keuangan pemerintah.

Sehingga Dapat disimpulkan bahwa aplikasi SILABI versi 19.0.5yang digunakan Bendahara Pengeluaran pada kantor BPKP Provinsi Sumatera Selatan sudah sesuai dengan hukum dan peraturan dalam upaya meningkatkan kualitas laporan keuangan 
pemerintah.

Berdasarkan hasil penelitian yang dilakukan secara langsung danwawancara dengan kasubag keuangandi kantor Perwakilan BPKP Provinsi Sumatera Selatan, dengan variabel 1) Laporan Pertanggungjawaban(LPJ), 2) Bendahara Pengeluaran, dan 3) Aplikasi SistemLaporan Bendahara Instansi (SILABI).

Penulis berpendapat bahwa tepat waktu, lengkap, dan Akurat akan secara simultan mempengaruhi proses pembuatan laporan pertanggung jawaban Bendahara Pengeluaran. Hasil penelitian, menunjukkan bahwa dalam meningkatkan ketepatan waktu penyampaian LPJbendahara pengeluaran dikantor Perwakilan BPKP Provinsi Sumatera Selatan harus realistis dengan menetapkan skala prioritas dan waktu. Sehingga dapat menghasilkan laporan pertanggungjawaban sesuai dengan jadwal yang telah ditetapkan dan diterima oleh KPPN.

Sejalan dengan hasil penelitian yang dilaksanakan oleh Sari. J (2017) tentang Kompetensi SDM, pendidikan dan pelatihan, disiplin kerja, motivasi, implementasi Sistem Informasi Manajemen Daerah berpengaruh secara simultan dan parsial terhadap ketepatan waktu penyampaian laporan pertanggungjawaban bendahara pengeluaran.

Sedangkan pengalaman, sertifikasi, beban kerja dan kesejahteraan Bendahara Pengeluaran di kantor PerwakilanBPKP sudah sesuai dengan peraturan dan perundang-undangan yang berlaku.Hal ini dapat dilihat dari hasil penelitian terhadap indicator-indikator yang telah diteliti.Hasil penelitian ini sejalan dengan penelitian Nurmala (2016) membuktikan bahwa kompetensi SDM secara simultan berpengaruh terhadap ketepatan waktu penyampaian laporan pertanggungjawaban. Begitu pula Dheny Agusthamb(2012) membuktikan bahwa kinerja Bendahara pada Kantor Pengadilan Negeri Kelas I B Palopo bisa dikategorikan baik dan telah berjalan sesuai dengan peraturan yang berlaku.

Pada setiap awal tahun anggaran Bidang P3A (Perencanaan, Pelaporan, dan Pembinaan APIP) akan mengajukan anggaran yang dibutuhkandan kemudian dituangkanke dalam Dokumen Pagu Anggaran (DPA), guna membiayai pelaksanaan kegiatan-kegiatan yang memerlukan dana. Setelah danatersebut cair kemudian digunakan untuk keperluan kantor. Kemudian Kuasa Pengguna Anggaran (KPA) sebagai pejabat mengelola keuangan, harus mempertanggung jawabkan kepada KPPN selaku Bendahara Umum Negara (BUN). Dimana pertanggung jawaban tersebut dibuat oleh bendahara pengeluaran yang diberi kewenangan oleh Pengguna Anggaran (PA) Perwakilan BPKP Provinsi Sumatera Selatan.

\section{KESIMPULAN}

Dari hasil penelitian dapat disimpulkan bahwa :

1. Pembuatan Laporan Pertanggung jawaban Bendahara Pengeluaran menggunakan aplikasi SILABI merupakan sistem informasi akuntansi, input proses output pada aplikasi SILABI mudah, dan untuk menciptakan karakteristik informasi akuntansi yang relevan, tepat waktu, akurat, dan lengkap. Sehingga dengan hal tersebut pembuatan LPJ bendahara pengeluaran sudah sesuai peraturan perundangundangan, efisien, ekonomis, efektif dan transparan untuk dilaporkan.

2. Laporan Pertanggungjawaban Bendahara Pengeluaran disusun berdasarkan Buku Kas Umum, buku-buku pembantu dan Buku Pengawasan Anggaran yang telah diperiksa dan direkonsiliasi oleh KPA atas nama KPA yang menyajikan informasi tentang keadaan pembukuan pada bulan pelaporan, meliputi saldo awal, penambahan, penggunaan,dan saldo akhir dari buku-buku pembantu; keadaan kas pada akhir bulan 
pelaporan, meliputi uang tunai di brankas dan saldo di rekening bank; hasil rekonsiliasi internal (antara pembukuan bendahara dengan UAKPA); penjelasan atas selisih (jika ada), antara saldo buku dan saldo kas yang dilakukan dengan aplikasi SILABI yang terintegrasi dengan aplikasi SAS.

3. Pembuatan LPJ Bendahara Pengeluaran dilakukan secara periodik. Dengan pertanggungjawaban secara administratif kepada Kuasa Pengguna Anggaran (KPA) dan pertanggungjawaban fungsional kepada KPPN yang disampaikan selambat-lambatnya tanggal 10 setiap bulannya. Penyampaian LPJ Bendahara Pengeluaran pada kantor Perwakilan BPKP Provinsi Sumatera Selatan sudah tepat waktu, lengkap, dan Akurat. Pengalaman, sertifikasi, beban kerja dan kesejahteraan yang melekat pada Bendahara Pengeluaran sudah sesuai peraturan yang berlaku. Dengan Aplikasi Sistem Laporan Bendahara Instansi (SILABI) versi terapdate 19.0.5. tertanggal 20 mei 2019, tersedia dan mudah didownload, use friendly, dan ada petunjuk penggunaannya.

4. Hambatan yang sering dihadapi menggunakan aplikasi SILABI dalam proses pembuatan LPJ bendahara pengeluaran adalah Human eror (Salah memasukkan akun), terlambatnya mengapdate aplikasi versi terbaru, dan kesulitan uang kecil.Login pada aplikasiSILABI sebagai bendahara pengeluaran berfungsi untuk melakukan perekaman dan pencatatan serta pelaporan pembukuan bendahara pengeluaran. Adapun LPJ bendahara pengeluaran dan berita acara pemeriksaan kas dapat dicetak setelah proses pencatatan transaksi pembukuan telah dilakukan. Kemudian untuk memelihara data transaksi bendahara, menghindari adanya kerusakan dan kehilangan data, harus dilakukan proses backup dan restore data bendahara.

5. Untuk mengatasi masalah dan hambatan yang dihadapi oleh Bendahara Pengeluaran maka upaya yang dilakukan, diantaranya: a) jika terjadi human eror pada aplikasi SILABI, maka Bendahara Pengeluaran akan menghapus, kemudian merubah dan merekamnya kembali, b) mengatasi terlambatnya mengapdate aplikasi versi terbaru, Bendahara Pengeluaran harus cepat mendapatkan info aplikasi ter-apdate dari KPPN, dan c) jika terjadi kesulitan uang kecil, maka Bendahara Pengeluaran akan melakukan pembulatan.

\section{SARAN}

Dalam melakukan proses pembuatan LPJ Bendahara Pengeluaran, hendaknya pihak-pihak terkait terutama antara pegawai dapat bekerjasama saling koordinasi dengan semaksimal mungkin dan secara professional. Dalam melakukan pencatatan dokumen-dokumen harus dilakukan lebih hati-hati dan lebih teliti agar tidak terjadi kesalahan. Sehingga dalam proses verifikasi dapat berjalan dengan baik dan dapat selesai tepat waktu. Diperlukan pengawasan yang baik supaya terciptanya dunia kerja yang efektif dan efisien.

\section{DAFTAR PUSTAKA}

[1] Buku Pintar Aplikasi SAS, Kantor Pelayanan Perbedahaarraan Negara, Metro, Modul Admin, 2018.

[2] Kelembagaan Perbankan, Gramedia Pustaka Utama, Jakarta, Thomas Suyatno, 2014.

[3] Manajemen Keuangan, PT Bumi Aksara, Jakarta, Harmono, 2011.

[4] Manajemen Perbankan, Kencana 
Prenada Media Group, Jakarta, Ismail, 2011.

[5] Manajemen Sumber Daya Manusia, PT Bumi Aksara, Hasibuan, 2012.

[6] Manajemen Sumber Daya Manusia, PT Bumi Aksara, Hasibuan, 2014.

[7] Metode Penelitian Bisnis, Sugiyono, Bandung,2008.

[8] Metode Penelitian Kuanititatif Kualitatif, Alfabeta Sugiyono, Bandung, 2010.

[9] Metode Penelitian Untuk Akuntansi Sebuah Pendekatan Praktis, Ekonisia

[10] Metode Riset Akuntansi, Penerbit Salemba Empat, Malang, Chandrarin, 2017.

[11] Pengantar Ilmu Ekonomi No 3, BPPE UGM, Ekonomi Internasional, Boediono, 2014.

[12] Pengantar Manajemen Keuangan, Kencana Prenada Media Group, Jakarta, Kasmir, 2010.

[13] Pokok-Pokok Analisa Laporan Keuangan, Edisi Pertama, Cetakan Delapan, Djawanto, PS 2011.

[14] Prosedur Penelitian Suatu Pendekatan Praktik, Edisi Revisi 2010, Rineka Cipta, Jakarta, Arikunto, 2010. 